\title{
Ultrasonic Shock-Wave as a Control Mechanism for Liposome Drug Delivery System for Possible Use in Scaffold Implanted to Animals with Iatrogenic Articular Cartilage Defects
}

\author{
A. MÍČKOVÁ ${ }^{1,2^{*}}$, K. TOMÁNKOVÁ ${ }^{3 *}$, H. KOLÁŘOVÁ ${ }^{3}$, R. BAJGAR ${ }^{3}$, P. KOLÁŘ ${ }^{3,8}$, P. ŠUNKA $^{4}$, M. $^{2}$ \\ PLENCNER $^{1,2}$, R. JAKUBOVÁ ${ }^{1,2}$, J. BENEŠ ${ }^{5}$, L. KOLÁC̆NÁ $^{1,2}$, L. PLÁNKA $^{6}$, A. NEČAS 7 , E. AMLER ${ }^{1,2}$ \\ ${ }^{1}$ Department of Biophysics, $2^{\text {nd }}$ Faculty of Medicine, Charles University in Prague, Prague, Czech Republic \\ ${ }^{2}$ Laboratory of Tissue Engineering, Institute of Experimental Medicine, Academy of Sciences \\ of the Czech Republic, Prague, Czech Republic \\ ${ }^{3}$ Department of Medical Biophysics, Faculty of Medicine, Palacký University, Olomouc, Czech Republic \\ ${ }^{4}$ Institute of Plasma Physics, Academy of Sciences of the Czech Republic, Prague, Czech Republic, \\ ${ }^{5}$ First Faculty of Medicine, Charles University in Prague, Prague, Czech Republic \\ ${ }^{6}$ Department of Pediatric Surgery, Orthopaedics and Traumatology, Faculty Hospital Brno, Czech Republic \\ ${ }^{7}$ Department of Surgery and Orthopaedics, Small Animal Clinic, Faculty of Veterinary Medicine, \\ University of Veterinary and Pharmaceutical Sciences Brno, Czech Republic \\ ${ }^{8}$ Department of Orthopaedics, University Hospital in Olomouc, Czech Republic
}

Received November 15, 2007

Accepted February 14, 2008

\begin{abstract}
Míčková A., K. Tománková, H. Kolářová, R. Bajgar, P. Kolář, P. Šunka, M. Plencner, R. Jakubová, J. Beneš, L. Koláčná, L. Plánka, A. Nečas, E. Amler: Ultrasonic ShockWave as a Control Mechanism for Liposome Drug Delivery System for Possible Use in Scaffold Implanted to Animals with Iatrogenic Articular Cartilage Defects. Acta Vet Brno 2008, 77: 285-289.

A short liposome exposure to ultrasonic waves with the intensity of $I=2 \mathrm{~W} / \mathrm{cm}^{2}$ at frequency $f=1 \mathrm{MHz}$ was found to be a sufficient tool for liposome opening. In addition, shock-wave proved to be sufficient also for liposome content release. Both methods are useful tools to be used as control mechanisms for drug delivery systems based on liposomes. However, due to better focusing and low non-thermal side effects, shock-waves probably have a markedly higher potential for successful use.
\end{abstract}

Liposome, controlled drug delivery, ultrasound shock-wave, fluorescence

Liposomes appear to be a promising tool for the development of drug delivery systems. Their membrane is composed of a lipid bilayer which is impermeable to ions and large dipoles, such as saccharides and proteins. Thus, encapsulated substances are protected from the environment and, in addition, liposomes are ideal carriers for water-soluble as well as lipid-soluble substances. Based on the properties mentioned above, liposomes can serve as convenient delivery vehicles for a variety of biologically active compounds (Matteucci and Thrall 2000). On that score, liposomes are often used as biocompatible carriers of drugs, peptides, proteins, plasmic DNA, antisense oligonucleotides or ribozymes, for pharmaceutical, cosmetic, and biochemical purposes (Ulrich 2002).

A wide range of liposomes varying in properties (e.g. size, colloidal behaviour, phase transitions, polymorphism), phospholipid composition or altered surface characteristics can be prepared with respect to the specific use (Banerjee 2001).

The exact mechanism of liposome breakdown after contacting the cell surface still remains rather speculative. The liposome may simply fuse with the plasma membrane or can be acquired by endocytosis or phagocytosis. Alternatively, the release of its content as a consequence of leakage, diffusion across the plasma membrane or pore formation may occur. Delivery of liposomal content also depends on temperature, pressure, and $\mathrm{pH}$ or particular target properties (Ulrich 2002).

Address for correspondence:

Evžen Amler, Assoc. Prof., PhD.,

Charles University in Prague, $2^{\text {nd }}$ Faculty of Medicine

Department of Biophysics

V Uvalu 84, 15006 Prague 5, Czech Republic
Phone: +420.257296350

Fax: +420.257296355

E-mail: evzen.amler@1fmotol.cuni.cz

http://www.vfu.cz/acta-vet/actavet.htm 
Surface modification of liposomes by ligand conjugation results in site-specific delivery of the liposomal content due to binding to particular receptors. Site-specific drug delivery can significantly reduce drug toxicity and increase the therapeutic effect (Anabousi et al. 2005).

Chemical instability induced by oxidation of unsaturated fatty acids and by hydrolysis of ester bonds and physical instability caused by drug leakage and by aggregation or fusion of vesicles to form larger particles can influence the in vivo behaviour of liposomes (targeting, cell uptake and clearance) (Sharma and Sharma 1997). Atomic force microscopy (AFM) is nowadays widely used for visualization of structures on a nanometre scale and found a broad application in biology, biotechnology, pharmacy, semiconductor devices, polymers, thin films and mineral surface (Siedlecki and Marchant 1998; Jandt 2001). AFM application for liposome stability and intactness control was demonstrated by Ruozi et al. (2005).

Drug-delivery system for cancer therapy was studied, based on drug encapsulation in polymeric micelles followed by a controlled release at the tumour site, triggered by ultrasound focused on the tumour (Rapoport et al. 2003). Non-hyperthermic ultrasound treatment significantly increased the effect of liposomally encapsulated cytostatic drugs on tumour growth (Myhr and Moan 2006). Acoustically active liposomes have the potential to carry pharmaceuticals and their acoustic activity could enable them to respond to ultrasound stimulation by releasing their contents. Content release of acoustically active liposomes was correlated with the loss of air induced by ultrasound (Huang and MacDonald 2004).

Fluorescent labelling is widely used for the biomolecule study (Abbott et al. 1991; Chen et al. 2006). Several fluorescence-based approaches can be utilized for liposome bursting, including fluorescence quenching or, in contrast, emergence as the consequence of liposomal content loosening.

\section{Materials and Methods}

Liposome preparation

One ml 1,2-dipalmitoyl-sn-glycero-3-phospocholine (DPPC, Avanti Polar Lipids, USA) (20 mg/ml, dissolved in chloroform : methanol) was pipetted into a round-bottom flask and the solvent was evaporated in a water bath at $50{ }^{\circ} \mathrm{C}$. The lipid film was hydrated at $45{ }^{\circ} \mathrm{C}$ by adding phosphate buffer saline (PBS, pH 7.4) and the total concentration was adjusted to $10 \mathrm{mg} / \mathrm{ml}$. Liposomes were then formed by passing the lipid suspension in the presence of the fluorescence probe propidium iodide 10 times through a polycarbonate membrane $(1 \mu \mathrm{m}$ pore size) using a miniextruder and heating block (Avanti Polar Lipids, USA) operating at the temperature of the lipid phase transition $\left(42^{\circ} \mathrm{C}\right)$.

Ultrasound treatment

Ultrasound generator BTL - 4000 (BTL, USA) with the transducer area of $4 \mathrm{~cm}^{2}$, frequency $1 \mathrm{MHz}$ and intensity $2 \mathrm{~W} \cdot \mathrm{cm}^{-2}$ was used for the sonication of liposomes in Eppendorf tubes. The ultrasonic intensity output from the transducer was calibrated by radiation force balance against a primary standard and a high performance hydrophone measurement system. Liposomes were sonicated for 1, 5, 10, 15, 20, 25, 30 min at a continuous rotation of $15 \mathrm{rpm}$ and a temperature of $37^{\circ} \mathrm{C}$.

Fluorescence measurement

We used the self-quenching property of the fluorescent probe propidium iodide at higher concentrations to study substance release from liposomes. Firstly, the threshold quenching concentration for the probe was determined from the dependence of the fluorescence intensity on the probe concentration. The extraliposomal probe was removed by gel filtration on a Sephadex column (Sephadex G10, Sigma). The increase of fluorescence intensity after sonication was measured by a fluororeader (Synergy HT reader, BioTek, USA).

Atomic force microscopy

The modified substrate poly-L-lysine (PLL) was placed on a plastic slide Thermanox at the concentration of $0.01 \%$ and incubated for $12 \mathrm{~h}$ under sterile conditions. One-hundred $\mu \mathrm{l}$ of liposomal suspension in PBS at a concentration of $10 \mathrm{mg} / \mathrm{ml}$ was put on the freshly modified substrate. The fixation was performed by drying the sample for $5 \mathrm{~min}$. For scanning we used the AFM Explorer microscope with a tipping head and a scanner with the scanning size of $100 \times 100 \mu \mathrm{m}$. The scans were evaluated by WSxM software (Horcas et al. 2007). 
Shock-wave experimental setup

The previously described experimental setup was modified (Šunka et al. 2006). A cylindrical composite anode consists of two insulated parts (A1 - $\varnothing 60 \times 70 \mathrm{~mm}, \mathrm{~A} 2-\varnothing 77 \times 20 \mathrm{~mm}$ ) energized from separate pulse power supplies that can be switched on with a different time delay. When they are switched on simultaneously, the shock wave from the larger diameter anode A 2 reaches the focus of $5 \mu$ s before the wave from the smaller diameter anode A1. The pulse power supplies consist of low inductive capacitors charged up to $30 \mathrm{kV}$ and two triggered spark gaps. The generator can produce either a single shock wave, or two successive waves focused on a common focal point. The amplitude of the shocks at the focus can be varied by surface areas of the anodes and by parameters of the discharge circuits, respectively. The generator has been placed in a tank where the conductive liquid is separated from the experimental volume containing distilled water by an acoustically transparent membrane.

\section{Results and Discussion}

\section{Ultrasound-stimulated liposome opening}

Liposomes were prepared from DPPC in PBS at $\mathrm{pH}$ 7.4. Liposomes (with a maximum diameter $d$ of $800 \mathrm{~nm}$ ) were found to form clusters due to surface charge-charge interaction of phospholipid polar heads. Atomic force microscopy before sonication clearly showed (Plate VII, Fig. 1A) a predominant presence of liposomes with a diameter of $600 \mathrm{~nm}$. Static sonication in ultrasonic bath led to liposome reformation (Plate VII, Fig. 1B). Already a short liposome exposure to ultrasonic waves with the intensity $I=2 \mathrm{~W} \cdot \mathrm{cm}^{-2}$ at a frequency $f=1 \mathrm{MHz}$ was found as a sufficient tool for liposome opening. Visualization by atomic force microscopy proved a cluster reorganization due to a higher presence of liposomes with a smaller diameter $(d=400-500 \mathrm{~nm})$. Clearly, liposomes were opened and again reformed after ultrasound application. Expectedly, this observation is in accordance with previous reports on liposome opening by ultrasonic waves. Reportedly, however, liposome reformation depends on the phospholipid composition. Consequently, our data clearly suggested opening and reforming of our DPPC lipid vesicles by a low intensity $1 \mathrm{MHz}$ ultrasonic wave.

\section{Ultrasound-stimulated release of liposome contents}

Propidium iodide was used to confirm our AFM data and to describe the release of contents quantitatively. We used a high self-quenching concentration of propidium iodide as liposome content. Opening and liposome reformation thus led to fluorophore release from the liposome vesicles. Consequently, the lowering of propidium iodide concentration resulted in an increase of fluorescence intensity. Ultrasound stimulation was time-dependent from $20 \mathrm{~s}$ to $30 \mathrm{~min}$. It should be mentioned that propidium iodide was released from the liposomes only partially (Fig. 2). This observation could reflect the fact that not all liposomes were opened and reformed after ultrasound stimulation. The reason could be either the stability of some portion of vesicles in clusters and/or the presence of multilamellar liposomes that were not completely opened.

Nevertheless, our results (Fig. 2) clearly show that the release half-time (time for release of half volume from liposomes) of ultrasonic stimulation with wave intensity $I=2 \mathrm{~W} \cdot \mathrm{cm}^{-2}$ at a frequency $f=1 \mathrm{MHz}$ was shorter than $1 \mathrm{~min}$. Clearly, using the shortest effective sonication time for the release of a substance from liposomes seems to be advantageous for practical application due to cell protection from ultrasound energy damage. In our previous work we studied the damage of MCF7 cells after application of a photodynamic and sonodynamic therapy, where the sonication time was 10 min (Kolářová et. al. 2007). Consequently, our release half-time seems to be promising for practical application of control drug delivery.

\section{Shock-wave-stimulated release of liposome contents}

Ultrasound-stimulated release of contents from liposomes, nevertheless, has some obvious disadvantages. Firstly, the targeting of stimulation is a rather difficult problem. Secondly, thermal as well as non-thermal effects are major obstacles in the use. Shock-waves seem to be a plausible alternative to solving targeting and to minimizing thermal effects due to the extremely short exposure lasting about $0.5 \mu$ s. Consequently, we applied shock-wave 


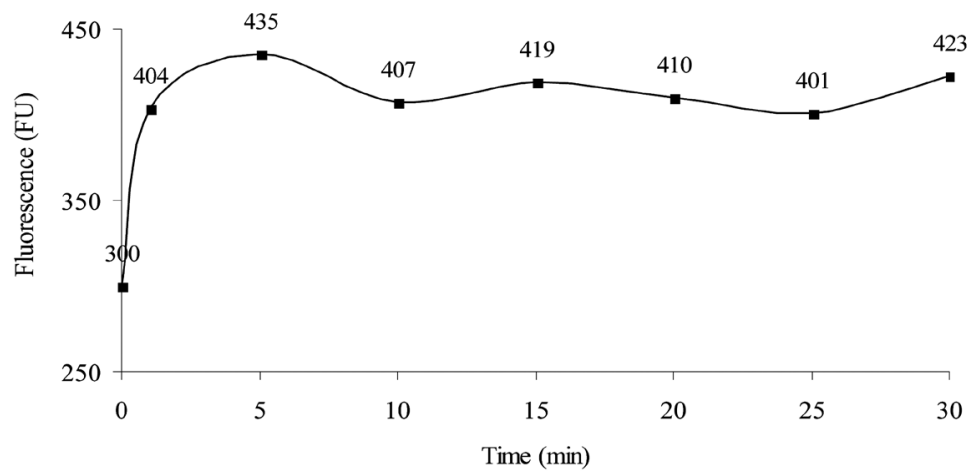

Fig. 2. Time dependence of propidium iodide fluorescence after ultrasound application (frequency $1 \mathrm{MHz}$ intensity $2 \mathrm{~W} \cdot \mathrm{cm}^{-2}$ ). The maximum fluorescence intensity (in arbitrary units marked as FU) was achieved in 5 min, the half time was lower than $1 \mathrm{~min}$.

stimulation to follow the content release from liposomes. Fluorescence intensities of selfquenching fluorescein concentration $(0.2 \mathrm{mM})$ were measured after a single and double ultrasonic shock-wave application (see Materials and Methods) over 2-30 min. Clearly, already the shortest time applications led to significant liposome bursting and to a liposome content release (Table 1). A double shock led in all cases to a virtually complete content release. Due to a very slight dependence of the content release after the first shock, we assume that the double shock released also the content from multilamellar liposomes rather than from the rest of unilamellar liposomes which remained unopened after the first shock-wave application.

Table 1. Fluorescence intensities detected after the single and double ultrasonic shock-wave

\begin{tabular}{|c|c|c|}
\hline Time & Fluorescence intensity Single shock (AU) & Fluorescence intensity Double shock (AU) \\
\hline $2 \mathrm{~min}$ & $8.7 \times 10^{5}\left( \pm 9.7 \times 10^{2}\right)$ & $11.5 \times 10^{5}\left( \pm 11.7 \times 10^{2}\right)$ \\
\hline $5 \mathrm{~min}$ & $7.2 \times 10^{5}\left( \pm 10.5 \times 10^{2}\right)$ & $11.5 \times 10^{5}\left( \pm 13.2 \times 10^{2}\right)$ \\
\hline $10 \mathrm{~min}$ & $10.4 \times 10^{5}\left( \pm 12.8 \times 10^{2}\right)$ & $12.6 \times 10^{5}\left( \pm 12.2 \times 10^{2}\right)$ \\
\hline $20 \mathrm{~min}$ & $8.1 \times 10^{5}\left( \pm 10.5 \times 10^{2}\right)$ & $12.5 \times 10^{5}\left( \pm 14.6 \times 10^{2}\right)$ \\
\hline $30 \mathrm{~min}$ & $9.9 \times 10^{5}\left( \pm 12.2 \times 10^{2}\right)$ & - \\
\hline
\end{tabular}

Ultrasound was applied for the indicated time; 1-minute application consisted of 30 shots

Our data clearly suggest that short-time ultrasound stimulation already at the intensity of $2 \mathrm{~W} \cdot \mathrm{cm}^{-2}$ at a frequency of $\mathrm{MHz}$ is a sufficient tool for liposome opening and reformation. In addition, our shock-wave application was also sufficient for the liposome content release. Consequently, both methods seem to be useful for application as control mechanisms for drug delivery systems based on liposomes. However, due to the highly advantageous properties of shock-waves, namely focusing and low non-thermal side effects, shockwaves probably have a markedly higher potential for a successful use as the triggering mechanism for liposome-based drug delivery systems.

\section{Ř́zené uvolňování léčiv z liposomů pomocí ultrazvukových rázových vln a možné využití v nosiči pro implantaci zvířatům s iatrogenním defektem kloubní chrupavky}

Krátkodobá ultrazvuková sonikace o intenzitě $\mathrm{I}=2 \mathrm{~W} \cdot \mathrm{cm}^{-2}$ a frekvenci $f=1 \mathrm{MHz}$ je postačující pro rozbíjení liposomů. Vhodnější metodou pro otevírání liposomů je však použití rázové vlny. Obě techniky sice mohou být využity pro řízené dodávání léčiv s využitím 
liposomů, ale díky lepší fokusaci rázové vlny a podstatně menším vedlejším negativním účinkům na organismus se jeví rázová vlna jako perspektivní nástroj pro řízené uvolňování léčiv z liposomů.

\section{Acknowledgement}

*Two authors (A. Míčková and K. Tománková) have contributed to this work equally. This work was supported by the Grant Agency of AS CR grants No. 1ET400110403 and IAA500390702, the Ministry of Education, Youth and Sport of the Czech Republic grants No. MSM 6198959216, 1M6798582302, NPV II 2B06130 and MSM 0021620808, and AVOZ 50390512 and AVOZ 50390703, and grant agency AGEL-MH.

\section{References}

ABBOTT AJ, AMLER E, BALL WJ, JR. 1991: Immunochemical and spectroscopic characterization of two fluorescein 5'-isothiocyanate labeling sites on Na+, K(+)-ATPase. Biochemistry 30: 1692-1701

ANABOUSI S, LAUE M, LEHR CM, BAKOWSKY U, EHRHARDT C 2005: Assessing transferrin modification of liposomes by atomic force microscopy and transmission electron microscopy. Eur J Pharm Biopharm 60: 295-303

BANERJEE R 2001: Liposomes: applications in medicine. J Biomater Appl 16: 3-21

HORCAS I, FERNANDEZ R, GOMEZ-RODRIGUEZ JM, COLCHERO J, GOMEZ-HERRERO J, BARO AM 2007: WSXM: a software for scanning probe microscopy and a tool for nanotechnology. Rev Sci Instrum 78 : 013705

HUANG SL, MACDONALD RC 2004: Acoustically active liposomes for drug encapsulation and ultrasoundtriggered release. Biochim Biophys Acta 1665: 134-141

CHEN C, YAO J, DURST R 2006: Liposome encapsulation of fluorescent nanoparticles: Quantum dots and silica nanoparticles. J Nanopart Res 8: 1033-1038

JANDT KD 2001: Atomic force microscopy of biomaterials surfaces and interfaces. Surf Sci 491: 303-332

KOLÁŘOVÁ H, BAJGAR R, TOMÁNKOVÁ K, KRESTYN E, DOLEŽAL L, HÁLEK J 2007: In vitro study of reactive oxygen species production during photodynamic therapy in ultrasound-pretreated cancer cells. Physiol Res 56: S27-S32

MATTEUCCI ML, THRALL DE 2000: The role of liposomes in drug delivery and diagnostic imaging: a review. Vet Radiol Ultrasound 41: 100-107

MYHR G, MOAN J 2006: Synergistic and tumour selective effects of chemotherapy and ultrasound treatment. Cancer Lett 232: 206-213

RAPOPORT N, PITT WG, SUN H, NELSON JL 2003: Drug delivery in polymeric micelles: from in vitro to in vivo. J Control Rel 91: 85-95

RUOZI B, TOSI G, FORNI F, FRESTA M, VANDELLI MA 2005: Atomic force microscopy and photon correlation spectroscopy: two techniques for rapid characterization of liposomes. Eur J Pharm Sci 25: 81-89

SHARMA A, SHARMA US 1997: Liposomes in drug delivery: progress and limitations. Int J Pharm 154: 123140

SIEDLECKI CA, MARCHANT RE 1998: Atomic force microscopy for characterization of the biomaterial interface. Biomaterials 19: 441-454

ŠUNKA P, STELMASHUK V, BABICKÝ V, ČLUPEK M, BENEŠ J, POUČKOVÁ P, KAŠPAR J, BODNÁR M 2006: Generation of two successive shock waves focused to a common focal point. IEEE Trans Plasma Sci 34: $1382-1385$

ULRICH AS 2002: Biophysical aspects of using liposomes as delivery vehicles. Biosci Rep 22: 129-150 


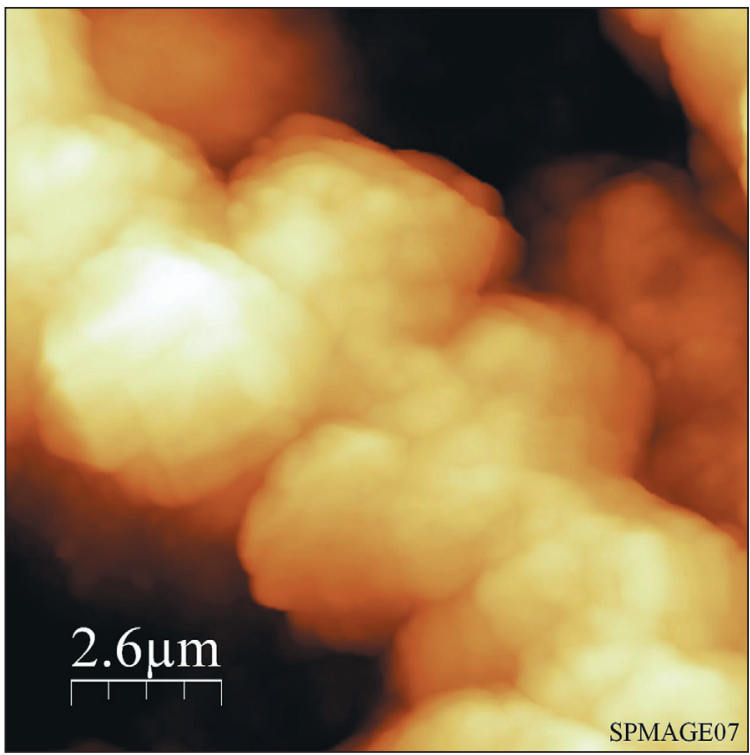

Fig. 1A: Intact liposomes before ultrasound application. Non-contact topography image mode; scanning size $13 \times 13 \mu \mathrm{m}$, scanning speed $20 \mu \mathrm{m} / \mathrm{s}$, resolution $300 \times 300$ pixels; height of liposomes is expressed in a scale from 0 (dark field) to 2.74 (light field) $\mu \mathrm{m}$

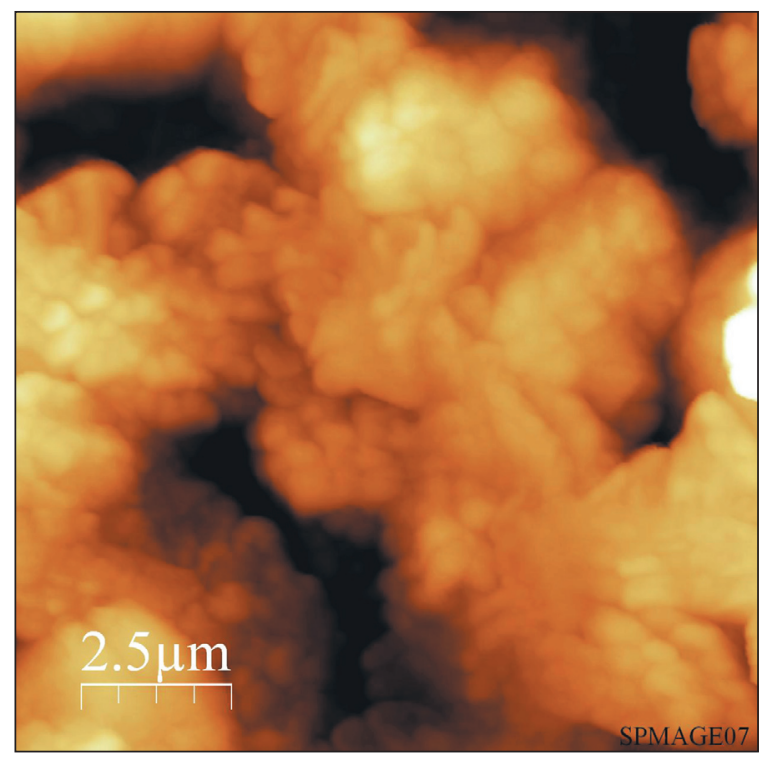

Fig. 1B: Burst liposomes after ultrasound application. Liposomes were treated by ultrasound (frequency $1 \mathrm{MHz}$, time of application $5 \mathrm{~min}$, intensity $2 \mathrm{~W} \cdot \mathrm{cm}^{-2}$ ). Non-contact topography image mode; scanning size $12.3 \times 12.3 \mu \mathrm{m}$, scanning speed $20 \mu \mathrm{m} / \mathrm{s}$, resolution $300 \times 300$ pixels; height of liposome destruction is expressed in a scale from 0 (dark field) to 923 (light field) $\mathrm{nm}$ 